\title{
Flashy tail, bony antlers
}

\author{
by Monica Harrington
}

\section{SCIENTIFIC NAME}

Odocoileus virginianus

TAXONOMY

PHYLUM: Chordata

CLASS: Mammalia

ORDER: Artiodactyla

FAMILY: Cervidae

\section{Physical description}

The white-tailed deer is an ungulate native to North, Central and South America. Adults stand about $3 \mathrm{ft}$ tall at the shoulder and weigh 150-200 lb. Coat color varies seasonally from reddish brown with short, sparse, wiry hairs during warm months to grayish brown with long, dense, brittle hairs and a thick undercoat in the colder months. Year round, the coat is marked with white on the underside of the body, on the inner areas of the legs and ears, around the eyes, across the muzzle and along the throat. The underside of the tail, which measures 6-11 in long, is also white, inspiring the deer's common name. The deer holds its tail erect when disturbed and bounds away with a flash of white. In addition to the showy tail, deer have prominent ears and bucks boast conspicuous antlers.

Antlers grow each spring and are usually shed the following winter. They develop from pedicles of the frontal bones of the skull. During growth, antlers are covered with highly vascularized tissue called velvet and are sensitive to damage. They harden once the velvet is shed. Antlers vary considerably in size and shape, with length and branching determined by nutrition, age and genetics, among other factors.

\section{Research résumé}

"Antlers are wonderfully complex and unique structures. They are among the fastest growing structures in nature [and] are the subject of human medical research for cancer, osteoporosis, and limb regeneration," according to Brian Murphy of Quality Deer Management Association, a nonprofit organization that aims to conserve white-tailed deer ${ }^{1}$. Indeed, a recent study of deer antlers led to a new hypothesis on the cause of osteoporosis, suggesting that it results not from a lack of calcium but from a lack of manganese, a mineral essential to calcium absorption ${ }^{2}$.

Although antler growth is well described, the underlying molecular mechanisms are poorly understood and are compelling

objectives for researchers "despite the obvious limitations of using deer as an experimental model, because this research will help provide insight into why humans and other mammals have lost the ability to regenerate organs" ${ }^{3}$. Research suggests that antler regeneration is controlled by the same signaling pathways that control skeletal development and that regeneration potential depends on the cues to which progenitor cells are exposed ${ }^{3}$. This in turn suggests that manipulation of the cellular environment could stimulate pluripotent cells in other adult mammalian tissues to increase their healing capacity ${ }^{3}$.

Other scientists have studied bone growth, hormone and mineral metabolism, and the genetic basis for different antler characteristics in white-tailed deer". Their goal is "to use an understanding of antler growth to improve therapies for human bone disease and fractures"4.

White-tailed deer are also used in research on Lyme disease, as they are the primary host for blacklegged ticks, which carry the bacterium that causes the disease in humans. Entomologists recently found that deer can be used as sentinels to identify geographical areas where Lyme disease might be endemic ${ }^{5}$.

Finally, white-tailed deer are susceptible to chronic wasting disease (CWD), a transmissible spongiform encephalopathy associated with aberrant prions, like bovine spongiform encephalopathy in cows and Creutzfeldt-Jakob disease in humans. CWD spreads by direct contact or exposure to contaminated food and water sources ${ }^{6}$. Research on CWD has contributed to our understanding of its pathogenesis and epidemiology, but its ecological, economic and public health implications remain to be fully recognized ${ }^{6}$.

1. Murphy, B. To Cull or Not to Cull: Reasons for Abnormal Antlers in White-tailed Deer (17 October 2011). <http://www2.outdoorchannel.com/article.aspx?id= 3643\&articletype=article\&key=To-Cull-or-Not-to-Cull--Reasons-for-AbnormalAntlers-in-Whitetailed-Deer>

2. Landete-Castillejos, T. et al. Alternative hypothesis for the origin of osteoporosis: The role of Mn. Front. Biosci. (Elite Ed.) 4, 1385-1390 (2012).

3. Price, J., Faucheux, C. \& Allen, S. Deer antlers as a model of Mammalian regeneration. Curr. Top. Dev. Biol. 67, 1-48 (2005).

4. Hewitt, D.G. \& DeYoung, R. Spinoffs from Deer Research at the CKWRI (July 2014). <http://www.ckwri.tamuk.edu/fileadmin/user_upload/docs/Deer_Research/ eNews_Archives/July_2014_Final.pdfs

5. Raizman, E.A., Holland, J.D. \& Shukle, J.T. White-tailed deer (Odocoileus virginianus) as a potential sentinel for human Lyme disease in Indiana. Zoonoses Public Health 60, 227-233 (2013).

6. Miller, M.W. \& Williams, E.S. Chronic wasting disease of cervids. Curr. Top. Microbiol. Immunol. 284, 193-214 (2004). 